\title{
The Sweat Factor in Bikram Yoga
}

\author{
Bradley Y. Bartholomew \\ Independent Researcher, France
}

Copyright $(2018$ by authors, all rights reserved. Authors agree that this article remains permanently open access under the terms of the Creative Commons Attribution License 4.0 International License

\begin{abstract}
It is common ground that the practice of hatha yoga will yield many health benefits, both physical and mental. Much of the recent research on hatha yoga has focused on Bikram Yoga, which differs from other forms of hatha yoga by virtue of it being practiced in an elevated ambient temperature which occasions profuse sweating, and is generally referred to as 'hot yoga'. Much of the recent research tends to be negative about this form of yoga, for instance Bikram yoga doesn't assist in removing impurities from the body, doesn't increase aerobic fitness and doesn't yield any more benefits, physically or mentally, than other schools of hatha yoga. This article reviews the sweaty rituals that have evolved throughout human history, principally the Buddhist and Hindu practices, the Greco-Roman baths, the Finnish Sauna, Russian Bania, Islamic Hammam, Japanese Mushi-Buro, the African sweat huts, Irish sweat mounds and the Native-American \& Eskimo sweatlodge, and it is shown that most of these sweaty traditions have a purification, rejuvenation and spiritual significance, and that human beings have a primary and primeval need to sweat. The fact that Bikram yoga resonates with this primeval need elevates it to a higher level than other schools of hatha yoga. The health benefits (both physical and mental) of profuse sweating are also presented, in particular that it rids the body of toxins such as arsenic, cadmium, lead, mercury and some pesticides and thus is a cleansing and rejuvenating process. But over and above the health benefits profuse sweating as a purification ritual is a major morale booster; it is a natural way to make us feel good and to make us feel good about our lives.
\end{abstract}

Keywords Cardiovascular, Hypertension, Hyperthermia, Blood Pressure, Arterial Stiffness

\section{Introduction}

There is now a considerable body of literature about the beneficial effects of hatha yoga. For instance it seems to be well settled that yoga reduces the risk of cardiovascular disease, [1] improves the quality of life for people suffering from diabetes and some forms of cancer, $[2,3]$ and yoga as well as mind-body therapies in general can switch off genes involved in inflammation (an immune-system overreaction implicated in numerous diseases), [4, 5] as well as significantly improve the state of mind and reduce the levels of anxiety for people suffering from depression, stress and eating disorders. [3] In general Bikram Yoga as a form of hatha yoga would also deliver these benefits to practitioners. In recent years most of the studies concentrate on Bikram Yoga because of its popularity, and we find that the studies tend to become negative in relation to the substantial benefits of this form of practice as a viable form of exercise. For instance it is said of Bikram Yoga that while a regular session can improve muscle strength, there is no effect on aerobic fitness. [6] A very recent study finds that the high ambient temperature of the Bikram yoga session provides no added benefits over and above other forms of hatha yoga. [7] All the studies on resting heart rate and systolic and diastolic blood pressure have reported that Bikram yoga delivers no significant change over time. All these studies were conducted on normotensive participants, that is to say their blood pressure was normal. Yet Bikram yoga practitioners have lower mean blood pressure and resting heart rates than national US averages, and there are studies which suggest that frequent and sustained Bikram yoga practice would reduce blood pressure. [8]

In this article it will be argued that profuse sweating on its own, regardless of what activity or exercise has caused it, has very significant beneficial effects, physically, mentally and even spiritually. The fact that profuse sweating occurs during a Bikram yoga session actually takes Bikram yoga to a higher level where it can be compared to the sweaty rituals and practices that have evolved in many diverse races and cultures throughout human history. The sweat factor in Bikram yoga seems to resonate with a primary and primeval human need.

\section{Sweaty Rituals}

It is impossible to overestimate the role of ritual in human society. In the last resort our whole life is just one long ritual. As a general rule we get up in the morning around the same time, we take our meals around the same 
time, and we do pretty much the same things every day. We are habitual creatures, and repetition and order and predictability are essential for our mental well-being. Our comfort zone consists of our familiar environment and our familiar occupations and pastimes, and as soon as we are taken out of our comfort zone neurosis will set in. Not only is our whole life in the nature of a ritual, but every single day is taken up with rituals. Work is a ritual, picking the kids up from school is a ritual, a game of golf is a ritual, shopping is a ritual, intercourse (both social and sexual) is a ritual, sleep is a ritual.

Our life is nothing but rituals within rituals within rituals. There are psychological rituals designed as a form of stress reduction and provide methods of gaining psychological insight into emotional problems, hypnotism and psychoanalysis for example. In all cultures there are rituals surrounding death which are designed to facilitate the expression of grief and the loss of a loved one. In various rites of passage the ritual serves to change status and identity within a group, such as the confirmation of adulthood. The twenty-first birthday party is a rite of passage ritual universally observed in western culture for example.

In many primitive cultures there are rituals to prepare men for battle and return from it. In modern western culture what is military training if not a ritual, as well as military funerals for the dead, medical and hospital facilities for the wounded, multifarious psychological and social rituals to facilitate the soldiers return to civilian life (especially for those soldiers suffering mental problems or Post-Traumatic-Stress Syndrome (PTSS) as a result of the horrors of war).

As we will be looking at the sweat lodge ritual of various Native American groups in this section I will mention that among some Native American groups, war is regarded as an abnormal condition and an aberration of the harmonious order of the universe. [9] Elaborate rituals are in place whereby the culture honors the warrior's acts of bravery and provides rituals to purge, purify, and heal the physical and psychological wounds of war as a means of transforming the warrior identity back to peace and harmony. Warriors who can't adjust to peace time and again find a strong bonding with their social milieu will likely suffer feelings of alienation and the assumption of a victimized state, with debilitating psychological consequences (e.g., alcoholism, depression, self-despair, and suicide). In most tribal groups the shaman of the culture assumes the role of healer or medicine person and performs rituals of various types designed to cure suffering and restore good health and spirituality to the victim.

Anthony F. C. Wallace, the distinguished anthropologist, has written that:

Efforts to induce an ecstatic spiritual state by crudely and directly manipulating physiological processes are found in every religious system. Such manipulations may be classified under four major headings: (1) drugs, (2) sensory deprivation, (3) mortification of the flesh by pain, sleeplessness and fatigue, (4) deprivation of food, water and air. [10]

The last three dimensions are commonly employed by various Native American groups as part of healing and purification rituals, especially in their sweat lodge ceremonies. The sweat lodge ceremony is widely used by many tribal groups and has physical, psychological, group-oriented, and spiritual dimensions that are potentially useful in alleviating emotional symptoms.[11]

In writing about various cultural and religious practices as a form of psychotherapy for the mentally ill, Wallace observes that they are designed to transform identity crises and maladaptive behavior.

These rituals of salvation are, in a sense, similar to rites of passage because they seek to effect a change in the career line of their subject; conversely, rites of passage, much as the Plains Indians' vision quest, may involve mystical phenomena in the course of identity change. The justification for setting aside a special category of salvation rituals lies in the fact that some identity crises are not universally anticipated in a society and are not treated with universally applied rites of passage, but rather are more or less ad hoc ceremonies performed by and upon only those persons who "spontaneously" enter into the experience for the sake of spiritual enrichment or salvation... The function of ritual, in these cases, is undoubtedly to provide a pattern for a process in remission of psychopathology which will bring the victim of severe mental illness out "on the other side." ... If the ritual is effective, he will arrive at a condition that will permit him to take care of himself and perform useful services (often ritual services) for the other members of the community. [10]

The sweat lodge purification ritual is a Native American religious event of thanksgiving and forgiveness which is typically led by a medicine person of the tribe. In the sweat lodge rituals of some of the tribes the lodge is regarded as the womb of Mother Earth and the ritual has a definite re-birthing aspect. Also in some legends the sweat lodge is personified and actually takes on a creative aspect responsible for the differentiating and survival of animal life similar to the Noah's Ark legend. [12] It is regarded as a serious and sacred occasion in which spiritual insights, personal growth, and physical and emotional healing may take place. The process of purification is experienced on many levels of awareness, including the physical, psychological, social, and spiritual. [11]

It is not necessary here to enter into the precise structure and conditions of the sweat lodge. It is obviously a ritual that is far more arduous and discomfiting than Bikram yoga. 
The interior of the lodge creates an encapsulated environment that produces feelings of claustrophobia and an urge to escape. The lodge is crowded since the members sit knee to knee in cross-legged fashion. There is not enough room to stretch out or alter one's posture of facing the pit. The space is configured in a circle which links the group together; there is both physical and symbolic unity. The group is bonded together in a common environment that is simultaneously a dark space void of light but full of stress and pressure generated by the heat, steam, and smoke. The early stages of the ceremony, especially prior to the first "door," are painful, distressing, and trying. The urge to escape to find relief is strong, yet there is nowhere to move and only one door to exit at, which is stationed near the medicine person. In response to these conditions the individual becomes acutely aware of his or her physical and psychological state. Physically, the body is attempting to adapt to the change in temperature and humidity. The heart beats rapidly; the breathing is shallow and quick, and sweating is profuse. There is an inner struggle to overcome the powerful urge to escape. Each participant must find a way to overcome the pain, suffering, and distress, while at the same time concentrating on the prayers and words of the leader and the other members. [11]

It is suggested that the instructor in a Bikram yoga session really does perform a role similar to the shaman in the sweat lodge ritual. The monologue by the instructor in a Bikram yoga session is essentially motivational and inspirational in nature. The participants are constantly being exhorted by the instructor to adopt a perfect posture and stretch their bodies to the extreme. It can be argued, of course, that the role of the shaman is not unlike the role of the psychiatrist, psychologist, or other health care providers who seek to help people with emotional or physical pain. What does differ, of course, is the cultural context, language system, and symbolic aspects in which the ritualized practice of healing takes place. But is it possible that the sweat lodge ritual contains an archetypal form of human experience that in some way transcends cultural diversity in producing a psychobiological state that is associated with a reduction of pain and of emotional distress and with changes in modalities of perceiving, evaluating, and thinking about oneself in relation to others and the world? [11]

The sweat lodge ritual is also said to induce altered states of consciousness which would potentially be quite radical, but there cannot be any doubt that the Bikram yoga ritual is specifically designed to induce a changed state of consciousness in the participants. While performing the asanas the emphasis is on complete focus on the body and the breath in particular to the exclusion of all other considerations, and during the periods of sivasana the emphasis is on total stillness and relaxation of the body as well as a meditation on the breath alone. Throughout the 90 minutes of the Bikram yoga ritual the instructor is attempting to get the participants into a state of mind where they do not have one single extraneous thought. This is surely an altered state of consciousness.

An altered state of consciousness for a given individual is one in which he clearly feels a qualitative shift in his pattern of mental functioning, that he feels not just a quantitative shift, but also that some quality or qualities of his mental processes are different. [13]

The conditions are obviously much more extreme in the sweat lodge ritual than in Bikram yoga. The combination of the heat, steam, and lack of ventilation creates a suffocating effect in which it is difficult to breathe with comfort. As a result, attention is focused on one's inner state and simultaneously on the words of others. There is a struggle with pain induced by the heat and cramped conditions. There is often a reported loss of time and near or actual dehydration, and many members described altered states of consciousness. [11] The conditions of the sweat lodge are likely to affect production of neuropeptides (endogenous opioids), which are commonly associated with both altered states of consciousness and psychological reports of calmness, euphoria, energy, and well-being. [11]

There have been a series of experiments that identified the existence of beta-endorphins and enkephalin and their loci in the brain as well as the mechanism which would establish that altered states of consciousness are associated with endorphin production. [14] Both the sweat lodge ritual and Bikram yoga involve the performance of a ritual in a heated environment thus occasioning extreme sweating that leads to an altered state of consciousness.

These conditions, as described above, were principally the participation in group activity with the understanding that this would result in a trance-like state for the individual concerned... It is reasonable to suggest that the ritualistic dance associated with the altered states of consciousness ... might be physiologically and/ or emotionally stressful enough, or might activate proprioceptive inputs so as to raise circulating levels of endorphins to levels that could result in states of relative analgesia. Besides these analgesic properties, morphine and other opiates are known for their euphoric effects. Thus, the conjecture seems reasonable that if the transfer of beta-endorphin through the blood-brain barrier at supraspinal levels, perhaps most importantly in limbic structures, is the same as that in the spinal cord, these altered states of consciousness might be due to the activation of this same pituitary mechanism by stress. [15]

It is suggested that the performance of hatha yoga postures in heated conditions that involve extreme sweating and induces an altered state of consciousness, with an emphasis being placed always on stretching and twisting and contorting various parts of the body to the 
absolute limit thus occasioning pain, will most certainly occasion the release of endorphins, although to a lesser extent than the sweat lodge ritual and extreme physical exercise in the heat in general. $[15,16,17,18,19,20,21$, 22]

The Bikram yoga ritual is conducted in an ambient environment heated to $40.6^{\circ} \mathrm{C}$. with a humidity at $40 \%$. As the average body temperature is between $37.5-38.3^{\circ} \mathrm{C}$. it is clear that the Bikram yoga ritual does induce mild hyperthermia in the participants. Sweating is the primary heat-loss mechanism for humans which dissipates heat by evaporation assuming sufficiently low humidity. The conditions for Bikram yoga rituals are conducive to minimal evaporation of sweat. It is well settled that endorphin release and hyperthermia are corelated. [23, 24, $25,26]$ In addition mild hyperthermia has multiple health benefits, and it is widely used in the practice of thermal medicine in general. [27]

The sauna as it is known in the western world today originates from Finland, and although the modern sauna bathing has no spiritual or religious significance, the 'sauna steam' was regarded as being synonymous with 'life' or 'soul' or 'spirit' in the Finnish tradition as well as countries with a language related to Finnish, such as Estonia, Latvia, Russia and Hungary. Indeed there was an old Finnish saying 'one should behave in the sauna as in church'. The Finns believed that a 'sauna elf' resided in the sauna that had to be placated and respected. In other words the sauna most definitely had a spiritual significance to start with. The Russian bania is very similar to the Finnish sauna and the original religious significance is even better documented. A quote from a Russian sorcerer:

We all know how man came into being. Man was created when God took a bania and sweated profusely. He dried himself off with straw and dropped the straw to earth where the Devil used the straw to create the body. Then later, God gave man his soul. [12]

Just as the Finnish sauna was the haunt of the 'sauna elf' the Russian bania was the haunt of the Bannik, that likewise had to be placated and respected lest he should become angry. To protect yourself from the Bannik, etiquette required making the sign of the cross before entering the bania, wishing your comrades a good bath and, when leaving, wishing the Bannik a hearty goodbye. Since the Bannik liked a clean room and bathed at least once a week, cleaning and heating the bania were duties that could not be neglected. The Bannik could control the quality of steam and could transform harmless steam into deadly coal gas if he wasn't satisfied. The third or fourth round of bathing was always reserved for the Bannik who liked to bathe alone in the dark. Soap, lye, and birch twigs were left behind for him. And a little extra because the Bannik sometimes invited his forest friends to join him sometimes the Devil himself. [19] The magical attributes of the sweat bath were the reason that the critical stages of a
Finn's and a Russian's life - birth, adulthood, marriage, and death - were conducted in the sauna or bania. [12]

The sauna and the bania is an extreme sensory experience. During the ritual they beat themselves in a very lively manner on the back and legs with switches made of slender twigs, generally of young birch trees. The apostle Andreas who visited Russia during missionary work in the $12^{\text {th }}$ Century reports:

'Wondrous to relate,' he said, ' 1 saw the land of the Slavs, and while I was among them, I noticed their wooden bath-houses. They warm them to extreme heat, then undress, and after anointing themselves with tallow, take young reeds and lash their bodies. They actually lash themselves so violently that they barely escape alive. Then they drench themselves with cold water, and thus are revived. They think nothing of doing this every day and actually inflict such voluntary torture upon themselves. They make of the act not a mere washing but a veritable torment.' [12]

The lashing with the birch tree switches causes the blood to rise to the surface of the skin which allows the heat to escape from their bodies quicker. They emerge from the bania with their skin gleaming with a pinkish hue. The report above describes drenching themselves with cold water after sweat bathing. The fact is that the water is likely to be close to freezing and it is very common for them to actually roll naked in the snow. [12] Such an extreme sensory experience would inevitably occasion such a release of endorphins as to put them into a state of euphoria, comparable even to religious ecstasy.

The Greco-Roman baths of ancient Greece and Rome likewise involved sauna bathing. The phrase 'cleanliness is next to godliness' seems to have first appeared in Babylonian and Hebrew texts but this seems to be the spirit of the sweaty rituals of the ancient Greeks and Romans as well. There is certainly an element of purification about them, a desire to become pure inside and out. Originally there were the Greek hot-air baths called laconica, that had important social aspects including rites of birth, rites of marriage and rites of death, as well as being adjunct to a gymnasium for physical sports and exercise. [12]

One of the original names for the Roman Baths was thermae which clearly conveys the significance of the sweat factor. The Romans had smaller hot baths called balneum which were on the same scale as the Greek laconica, and the thermae were on a much grander scale. Successive Roman emperors tried to outdo each other in the grandeur of the thermae they had constructed. The Diocletian bath had a capacity for 6,000 bathers. Most thermae walls enclosed sports centers, swimming pools, parks, libraries, little theaters for poetry readings and music, and great halls for parties - a city within a city. The ritual generally involved physical games and exercises beforehand. Afterwards, the bather would trek through three rooms, progressing from tepid to hot, called 
tepidarium, caldarium and laconicum respectively. The body was primed for a vigorous massage, followed by a scraping off of dead skin with the strigil. A thorough scrubbing and a cool dip in the pool of the frigidarium was next.[12] Generally the healing properties of the hot baths were thought to be the work of the gods. Often the Roman baths were constructed adjacent to a temple, and sometimes indeed the temple would be part of the bath complex, as for example the Roman Baths at Bath in England. Although the Roman baths were primarily places for the pursuit of physical well-being and entertainment, the Christians denounced these 'Cathedrals of Flesh' as part of their opposition to pagan rituals in general.

Physical purification is a very significant part of the Moslem faith, and the Turks actually constructed their hammans as if they were temples. The Arabs encountered the Greco-Roman baths in Syria but it was not until Muhammed himself enthusiastically recommended sweat baths around 600 C.E. that the Islamic hammam began to proliferate. Muhammad believed that the heat of the hammam (which in Arabic means "spreader of warmth") enhanced fertility, and the followers of the faith should multiply. The hammam gained religious significance and became an annex to the mosque, and was used to comply with the Islamic laws of hygiene and purification. [12]

Interestingly the Turkish version of the hamman the so-called Turkish Bath includes a very vigorous massage as part of the ritual. The massages are administered by tellaks who are very powerful muscular men. The massage is very forceful. According to one participant describing the tellaks working on a group of Swedish visitors: "They began pulling, twisting, kneading and pummeling them like lumps of dough. One tellak seemed determined to see how many different pretzel shapes he could make out of a skinny Swede". When it became this participant's turn to be massaged he says: "The tellaks' style and control were remarkable - powerful, relentless, yet agreeable. With joints cracking and muscles stretching, he pushed and urged the tips of my toes to touch the back of my neck, just to the point of excruciating pain, and then a quick release, triggering a flood of electric tingles down my spine, canceling my urge to scream. A surging pleasure rushed in where the pain had been". [12] The similarities between these massages and Bikram yoga postures are obvious, and Bikram yoga is evidently just a less strenuous variation on a theme with the Islamic hamman, which has in turn been compared with the sport and exercise of the Roman bath. [12]

Communal sweat lodges very similar to the sweat lodges of the Native-Americans were common in Ireland until the $19^{\text {th }}$ Century. Nothing is known about how the custom of hot air bathing originated in Ireland. They may have been introduced to it by invading Vikings in the $8^{\text {th }}$ Century. They were primarily thought to have therapeutic benefits as well as giving the bathers a sense of well-being and cleanliness. 'Young women, wishing to improve their complexion after making peat or pulling flax, used to have the sweat bath, as it removed the kells, or stains and made them look nice and white'. -Rev. D.B. Mulcahy, “An Ancient Irish Hot-Air Bath" [12]

Just as rustic as the sod mounds of Ireland were the thatched sweat huts in Africa. Heat and sweating is one of the basic remedies for all kinds of ailments in tribal Africa south of the Sahara. [12] In the late 18th century, Mungo Park wrote:

African diseases are but few in number. On the first attack of fever, when the patient complains of a cold, he is frequently placed on a sort of vapor bath; this is done by spreading branches of the nauclea orientalis upon hot wood embers, and laying the patient upon them, wrapped up in a large cotton cloth. Water is then sprinkled upon the branches, which descending to the hot embers, soon covers the patient with a cloud of vapor, in which he is allowed to remain until the embers are almost extinguished. This practice commonly produces a profuse perspiration and wonderfully relieves the sufferer.

Writing of the Tanzanian Bantu in 1927, Henri Junod talks of a kind of Turkish vapor bath that is administered in certain complaints and also after the funeral rites, in order to remove the contamination of death. It is also administered in most cases where ritual defilement is feared, or is believed to have caused the disease. This vapor bath is also used as a last resort for couples not successful in having children. [12] Evidently then some of the sweaty rituals in Africa took on a purification significance in the sense of ridding the body of evil spirits as well as unhealthy toxins.

The Japanese actually derived their passion for sweat baths from Buddhist practices, and therefore have an explicit religious significance. The sauna is very popular in Japan in modern times, and there are several varieties of traditional sweat bathing rituals most of which are no longer practiced. The mushi-buro (steam bath), kama-buro (kiln bath) resembling a kiln, ishiburo (rock bath) a cave drilled into the side of a rock formation, kara-buro (empty bath) empty of water and filled with hot air or steam, todian-buro (shelf bath) and the Zaku roguchi, known as the Pomegranate Entrance bath.[12] Although there are no physical remains of the originals, there are many references to them in scrawled writings on temple walls.

A few kara-buros still remain in Kyoto which is the ancient capital of Japan, and where there are hundreds of Buddhist temples. The proximity of the kara-buro to the temples indicates the importance of cleanliness and purification in the Buddhist faith. To pray before Buddha, the reverent must be clean and smell natural. When priests and monks bathe, they follow a strict discipline of 25 commandments. Bathing is not only synonymous with ablution and purification, but it also brings sevenfold luck, prevents or cures the seven diseases of the skin. Shintoism, 
Japan's second religion, also teaches that one must bathe in order to become one with God. [12]

Indian Buddhist monks introduced the sauna to China from where it spread to Korea and eventually to Japan. The Daito Seiiki Diary by Genjo Sanzo (602-664 C.E.), mentions Chinese Buddhist temples with saunas that were open to the public. These saunas also provided medicine and food for the benefit of the poor and the sick. From the introduction of Buddhism in Japan during the Nara Period, many of the larger temples had saunas from which the modern baths, the sento, evolved. In the beginning these baths were meant mainly for the monks but occasionally they were open to others. Records mention that the wife of the Emperor Shomu, Koumyou Kougou (701-760 C.E.) allowed the sick the opportunity to bathe six days every month and even personally washed them. From the Kamakura period (1185-1333 C.E.), it was normal to make temple baths available for the sick. [28]

\section{The Spiritual Aspect of Hatha Yoga}

Hinduism is a set of religious beliefs and practices that are prescribed as 'a way of life' for its adherents. The earliest texts, the Vedas, date back 3,500 years. The primary theology of Hinduism is the cosmic intelligence, Brahman, and the Atman or the individual self. The physical practices of Hinduism enable the adherents to be at one or commune with the divine Inner Self. As 'a way of life', cleansing rituals and yoga are physical practices of the utmost importance. The oldest know medical document, the Ayurveda, appeared in Sanskrit in 568 B.C.E. and considered sweating so important to health that it prescribed the sweat bath and thirteen other methods of inducing sweat. [12] Likewise in Buddhism, which is an offshoot of Hinduism, sweat bathing was a purification ritual for the monks that eventually spread from India to China, Korea and Japan and indeed everywhere where Buddhism gained a foothold.

Yoga means 'to listen' in Sanskrit, and incorporates physical, mental and spiritual practices that are an integral part of Hinduism, Buddhism and Jainism. Hatha yoga is just one aspect of yoga which in modern times incorporates posture and breathing exercises. But even these have a clear religious significance. For a start they are merely two parts of Patanjali's Ashtanga Yoga (Eight-limbed Yoga) which represents a comprehensive statement of Hinduism as 'a way of life'. The postures are called asanas, the plural of asana which literally means 'seat' and in Patanjali's Sutras refers to the seated position used for meditation. Likewise the breathing exercises are referred to by Patanjali as pranayama, which involves a total focus on the prana (breath) as a means of focusing on the divine Inner Self. The Brhadāranyaka Upanishad states: "That which breathes by the breath is thy soul which is within every being". [29] To concentrate exclusively on the breath is as much an act of religious devotion as to meditate on, or chant the name of, or to sing hymns to the Godhead.

\section{The Bikram Yoga Ritual}

Bikram yoga takes its name from Bikram Choudhury who developed it in the 1980s. [30] Whereas other schools of hatha yoga have their set postures and procedures, the first thing that differentiates Bikram yoga is the ritual like nature of the sessions. The 90 minutes session consists of a set of 26 asanas which are repeated once for a precise amount of time and two breathing exercises. The session starts with standing pranayama (deep breathing - and one of the eight limbs of Patanjali's system mentioned above) followed by the standing asanas (45-50min). The standing sequence is followed by a 2 min savasana (supine relaxation, i.e., corpse pose) and a sequence of floor asanas (35-40min). A 20 -second savasana is taken between each asana in the floor series. Class finishes with a seated kapalabhati breathing exercise (i.e., quick, strong exhalations) and a final savasana.

All these asanas are of course another of the eight-limbs of Patanjali's Ashtanga yoga mentioned above. One entire wall of the studio is mirrored and all the participants have to look at themselves in the mirror as they perform the asanas. Effectively they are meditating on, or contemplating, the effectiveness of their own practice. Not only are they performing a ritual, but they are watching themselves perform it which adds another level of absorption in the ritual. In addition to the specific pranayama at the beginning and end of the session, the entire 90 minutes is in fact an exercise in pranayama in as much as the participants are required to focus on their breath as they perform the asanas as well as the periods of savasana. In other words the entire 90 minutes is a period of deep meditation where the participants can enter a trance like state and become completely unaware of the passage of time.

The second major difference with Bikram yoga is throughout the entire 90 minutes there is an instructor who delivers a motivational monologue. Scientific papers that have been written about Bikram yoga sometimes refer to it as an 'instructional dialogue' but it is much more than this. [31] The instructor actually performs the role of a shaman who is constantly enjoining the participants to perform the asanas to the very best of their ability as well as give it that little bit of something extra, and then during the periods of savasana the perfect practice requires absolute stillness and complete and total concentration on the breath. The tone of the instructor will change during the savasana, but still the message is encouraging the participants to achieve the sublime state. This motivational monologue takes the meditation aspect of Bikram yoga to an even deeper level. It is an integral part of the ritual.

The third major difference with Bikram yoga is that the 
entire 90 minutes of the ritual is performed in a room heated to $40.6^{\circ} \mathrm{C}$, and with a humidity of $40 \%$. In other words it is slightly hotter than the normal body temperature, and there is profuse sweating and minimal evaporation. Bikram yoga is performed in a sauna.

\section{The Health Benefits of Sauna Bathing}

Most of the research material on sauna bathing relates to the Finnish sauna where the temperature is around $80-100^{\circ} \mathrm{C}$. with humidity around $15-20 \%$, so it is considerably hotter and substantially drier than the Bikram yoga room. It is suggested however that the volume of sweat generated in Bikram yoga would be comparable because normally a Finnish sauna involves 2-3 sessions of 10-20 minutes duration where participants are in a static seated position, whereas Bikram yoga is a continuous 90 minute course of hatha yoga postures. On the assumption that the volume of sweat generated is about the same, it is reasonable to assume that the same metabolic and physiological processes are occurring.

As regards the cardiovascular effects of Finnish sauna, the peripheral circulation increases, the circulation to muscles, kidney and viscera decreases, metabolic rate and oxygen consumption increases, water loss occurs with maximal cutaneous circulation, the heart rate increases and blood pressure, both systolic and diastolic, can drop.[32] With Bikram yoga, however, the blood circulation to the muscles would be expected to increase on account of the hatha yoga postures.

For the physiological effects of Finnish sauna, there is increased plasma cortisol, corticosteroids, growth hormone, thyroid-stimulating hormone (TSH) and prolactin. Bronchodilation occurs along with muscle relaxation and decreased activity of neuromuscular system. There is loss of water along with the electrolytes $(\mathrm{Na}, \mathrm{K}, \mathrm{Cl})$ and this is compensated through hormonal regulation of kidneys of aldosterone secretion. Lypolysis (the breakdown of fats) also occurs. [32] Here as well with Bikram yoga there would not be the muscle relaxation and the decreased activity of the neuromuscular system.

Numerous compounds are released in the sweat. The minerals sodium, potassium, magnesium and chloride are all excreted via sweat along with iron and chromium. Sodium and chloride have the greatest losses, and magnesium and potassium in much lower quantities. Copper and zinc are also released in high amounts, and nickel and lead to a lesser extent than copper and zinc. [32]

There is a plethora of research data on the health benefits of sauna bathing. The cardiovascular system in particular (including hemodynamics, arterial stiffness and blood pressure) is benefited.[33, 34, 35, 36, 37, 38, 39, 40, 41, $42,43,44,45]$ Sauna bathing can reduce total cholesterol levels. [46] The vasodilation in a low-temperature sauna bath improved the peripheral circulation in cerebral palsy patients, and may be beneficial for other severe motor and intellectual disabilities. [47] It has been argued that the human body thermoregulatory system has a corollary relationship to the cardiovascular system, and that we therefore have an inherent need to exercise our thermoregulatory system, in other words we have an inherent need to sweat in order to optimize our health. [48]

The transient improvements in pulmonary function that occur in the sauna may provide some relief to patients with asthma and chronic bronchitis.[36, 38, 49] Sauna bathing may also alleviate pain and improve joint mobility in patients with rheumatic disease. [36] Also regular sauna bathing has a protective effect on skin physiology, [53] and can improve impaired insulin sensitivity for diabetes sufferers. [44] It will improve longevity. [37, 50, 51]

Sweat is the principle means by which toxic elements such as arsenic, cadmium, lead and mercury are excreted from the body, $[38,54,55,56]$ and in addition some pesticides are excreted in sweat. [57, 55] Sweating is truly a cleansing process. Sauna bathing after physical exercise will increase the endurance of athletes. [58] Minerals and trace elements are excreted in sweat, [40] so for example sufferers of Wilson's disease would benefit from excretion of copper. [59] Neuroendocrine activity (release of hormones ACTH and prolactin) and women's heart rate are significantly higher than in men, [60] growth hormone increases for both sexes, [61] there is an increase in plasma catecholamine and glucagon levels as well as significant sodium depletion, [45, 62] and in a study on men only, blood concentrations of beta-endorphin immunoreactivity and testosterone were also increased. [41]

Sauna bathing has many mental benefits as well. It will reduce the risk of dementia and Alzheimer's disease. [52] There was a significant rise in plasma levels of beta-endorphins after a $47^{\circ} \mathrm{C}$. Japanese hot-springs bath which is said to explain the feeling of 'intoxication' often experienced. [63] Sauna bathing will reduce oxidative stress after aerobic exercise,[64] and may be beneficial for relief of negative psychological states in general such as stress, tension, anxiety, depression, dejection, anger, hostility, fatigue and confusion. [65, 66, 67] Sweat therapy enhances group counseling sessions in psychotherapy, where those in a sweat group counseling condition were found to have a more positive and optimistic state of mind. [68]

\section{Health Benefits of Mind-Body Therapies Generally}

There is an ever-growing body of literature concerning the relationship between exercise, physical activity and physical and mental health. The physical benefits include improvements in obesity, cancer, cardiovascular disease and sexual dysfunction, and mental benefits such as the 
alleviation of depression and other negative mood states.[69] A major subset of this literature involves the so-called 'mind-body' therapies, such as yoga, Tai Chi, Body-Oriented Psychotherapy, Body Awareness Therapy, mindfulness based therapies/meditation, Feldenkrais, Alexander Method, Breath Therapy and others, that have this common ground of 'body awareness'. At an abstract or philosophical level these therapies facilitate 'a progression towards greater unity between body and self'.[70] The physical and mental benefits include management of pain [71], improvement in musculoskeletal disorders [72], stress reduction [73], alleviation of a slew of menopausal problems [74], complementary treatments for breast and prostate cancer [75], alleviation of problems related to pregnancy [76], reduces inflammatory markers and influences anti-viral immune responses [77], relief of migraine headaches [79], enhanced bone density [80], cardiopulmonary benefits [80], improving balance and reducing the number of falls [80] as well as generally being perceived as beneficial in 'preventing illness or maintaining health and vitality' [78] and improving 'quality of life'.[80]

\section{Conclusions}

It is common ground that Bikram yoga as a form of hatha yoga and as a mind-body therapy is a viable form of physical exercise that will deliver a wide range of physical and mental benefits to the practitioner. In addition people who practice hatha yoga on a regular basis develop a mind-set where there practice is more than just a physical exercise but is more in the way of a 'way of life' where they will take an interest in the spiritual side of yoga practice and will make other lifestyle and dietary decisions that they consider part and parcel of that 'way of life'. This applies to adherents of Bikram yoga as much as to any of the other schools of hatha yoga, but the fact that an essential additional feature of Bikram yoga is profuse sweating will not only bring with it added health benefits that have been verified scientifically, but also a session of Bikram yoga as a sweaty ritual has elevated it in a less tangible way to a semi-ecstatic, mildly euphoric exercise of spiritual rejuvenation and purification.

Substantial evidence has been given above that sauna bathing and heat therapy in general produces many positive psychological effects, and it is hoped that sufficient material has been provided in this article, to make the case that statistically there must be an enhanced euphoric and spiritual factor in a sweaty ritual by virtue of the diverse number of races and cultures throughout human history who have independently developed them, and practice them not only with enthusiasm but also with reverence. Statistically a case can be made that for humans profuse sweating as a purification ritual is a major morale booster; it is a natural way to make us feel good and to make us feel good about our lives.

\section{REFERENCES}

[1] Cramer, H., Lauche, R., Haller, H., Steckhan, N., Michalsen, A., and Dobos, G. (2014) Effects of yoga on cardiovascular disease risk factors: a systematic review and meta-analysis, International Journal of Cardiology, 173(2).

[2] Jyotsna, V.P., Joshi, A., Ambekar, S., Kumar, N., Dhawan, A., and Sreenivas V. (2012) Comprehensive yogic breathing program improves quality of life in patients with diabetes, Indian Journal of Endocrinology and Metabolism, 16(3).

[3] De Lange, C., (2018) No sweat: Is yoga a proper workout? New Scientist, 10 January, 2018.

[4] Li, Q.Z., Li, P., Garcia, G.E., Johnson, R.J., and Feng, L. (2006) Genomic profiling of neutrophil transcripts in Asian Qigong practitioners: a pilot study in gene regulation by mind-body interaction, Journal of Alternative Complementary Medicine, 11(1).

[5] Irwin, M.R., Olmstead, R., Breen, E.C., Witarama, T., Carrillo, C., Sadeghi, N., Arevalo, J.M., Ma, J., Nicassio, P., Ganz, P.A., Bower, J.E., and Cole S. (2014) Tai chi, cellular inflammation, and transcriptome dynamics in breast cancer survivors with insomnia: a randomized controlled trial, Journal of the National Cancer Institute Monographs, 50.

[6] Tracy, B.L., Hart, C.E. (2013) Bikram yoga training and physical fitness in healthy young adults. Journal of Strength and Conditioning Research, 27(3).

[7] Hunter, S.D., Laosiripisan, J., Elmenshawy, A., and Tanaka, H. (2018) Effects of yoga interventions practised in heated and thermoneutral conditions on endothelium-dependent vasodilatation: The Bikram yoga heart study, Experimental Physiology, DOI: 10.1113/EP086725.

[8] Hewett, Z., Cheema, B.S., Pumpa, K.L. and Smith, C.A. (2015) The Effects of Bikram Yoga on Health: Critical Review and Clinical Trial Recommendations, Evidence-Based Complementary and Alternative Medicine, Article ID 428427.

[9] Silver, S., \& Wilson, J. P. (1988). Native American healing and purification rituals for war stress. In J. P. Wilson, Z. Harel, \& B. Kahana (Eds.), Human adaptation to extreme stress: From the Holocaust to Vietnam. New York: Plenum Press.

[10] Wallace, A.F.C. (1966). Religion. New York: Random House.

[11] Wilson, J. P.. Trauma, Transformation, And Healing: An Integrated Approach To Theory Research \& Post Traumatic Therapy (1989) (Psychosocial Stress Series). Taylor and Francis. Kindle Edition.

[12] Aaland, Mikkel. (2017) Sweat: The Illustrated History and Description of the Finnish Sauna, Russian Bania, Islamic Hammam, Japanese Mushi-Buro, Mexican Temescal, and American Indian \& Eskimo. Kindle Edition.

[13] Tart, C. J. (Ed.) (1969). Altered states of consciousness. New 
York: Wiley.

[14] Henry, J. L. (1982). Possible involvement of endorphins in altered states of consciousness. Ethos, 10(4).

[15] Follenius M1, Candas V, Bothorel B, and Brandenberger G. (1989) Effect of rehydration on atrial natriuretic peptide release during exercise in the heat, Journal of Applied Physiology, 66(6).

[16] Armstrong, D.W. and Hatfield, B.D. (2006) Hormonal responses to opioid receptor blockade: during rest and exercise in cold and hot environments, European Journal of Applied Physiology, 97(1).

[17] Nijs, J., Kosek, E., Oosterwijck, J.V., Gent, U. and Meeus, M. (2012) Dysfunctional endogenous analgesia during exercise in patients with chronic pain: to exercise or not to exercise? Pain Physician. 15(3S).

[18] Hickey, M.S., Franke, W.D., Herbert, W.G., Walberg-Rankin, J., and Lee, J.C. (2007) Opioid Antagonism, Perceived Exertion and Tolerance to Exercise-Thermal Stress, International Journal of Sports Medicine, 13(4).

[19] Balchina, R., Linde, J., Blackhurst, D., Rauch, H.G.L., and Schönbächlere, G. (2016) Sweating away depression? The impact of intensive exercise on depression, Journal of Affective Disorders, 200.

[20] Melin, B., Curé, M., Pequignot, J.M., and Bittel, J. (1988) Body temperature and plasma prolactin and norepinephrine relationships during exercise in a warm environment: effect of dehydration, European Journal of Applied Physiology and Occupational Physiology, 58(1-2)

[21] Kelso T.B. (1983) Possible thermoregulatory contributions of plasma - endorphin during prolonged exercise in humans, Virginia Polytechnic Institute and State University Virginia.

[22] Yehuda, S. and Kastin, A.J. (1980) Peptides and thermoregulation, Neuroscience Biobehavior Revue, 4(4).

[23] Holaday JW, Faden AI. (1980) Naloxone acts at central opiate receptors to reverse hypotension, hypothermia and hypoventilation in spinal shock, Brain Research, 189(1).

[24] Jezová D., Vigas, M., Tatár, P., Jurcovicová, J. and Palát, M. (1985) Rise in plasma beta-endorphin and ACTH in response to hyperthermia in sauna, Hormone and Metabolic Research, 17(12).

[25] Millan, M.J., Przewlock, R., Jerlicz, M., Gramsch, C.H., Höllt, V., and Herz, A. (1981) Stress-induced release of brain and pituitary $\beta$-endorphin: Major role of endorphins in generation of hyperthermia, not analgesia, Brain Research, 208.

[26] Bläsig, J., Höllt, V., Bäuerle, U., and Herz, A. (1978) Involvement of endorphins in emotional hyperthermia of rats, Life Sciences, 23(25).

[27] Crinnion, W.J., (2011) Sauna as a valuable clinical tool for cardiovascular, autoimmune, toxicant-induced and other chronic health problems. Alternative Medicine Review, p. 215

[28] Guide to Buddhism A to Z http://www.buddhisma2z.com/content.php?id=482
[29] Doer, E., (1978) Bŗhadāranyyaka Upanişad. Delhi: Nag Publishers.

[30] B. Choudhury, B., (2007) Bikram Yoga, HarperCollins, New York.

[31] Hewett, Z.L., Cheema, B.S., Pumpa, K.L., and Smith, C.A (2015) The Effects of Bikram Yoga on Health: Critical Review and Clinical Trial Recommendations, Evidence-Based Complementary and Alternative Medicine.

[32] Crinnion, W., (2007) Components of Practical Clinical Detox Programs - Sauna as a Therapeutic Tool, Alternative Therapeutic Health Medicine, 13(2).

[33] Crinnion, W., (2007) Components of Practical Clinical Detox Programs - Sauna as a Therapeutic Tool, Alternative Therapeutic Health Medicine, 13(2).

[34] Lee, E., Laukkanen, T., Kunutsor, S.K., Khan, H., Willeit, P., Zaccardi, F. and Laukkanen, J.A. (2018) Sauna exposure leads to improved arterial compliance: Findings from a non-randomised experimental study, European Journal of Preventive Cardiology, 25(2)

[35] Laukkanen, T., Knutsor, S.K., Zaccardi, F., Lee, E., Willeit, P., Hassan, K., and Laukkanen, J.A. (2017) Acute effects of sauna bathing on cardiovascular function, Journal of Human Hypertension, doi: 10.1038/s41371-017-0008-z. [Epub ahead of print]

[36] Hannuksela, M.L., and Ellahham S. (2001) Benefits and risks of sauna bathing, The American Journal of Medicine, $110(2)$.

[37] Laukkanen, T., Khan, H., Zaccardi, F., and Laukkanen, J.A. (2015) Association Between Sauna Bathing and Fatal Cardiovascular and All-Cause Mortality Events, JAMA Internal Medicine, 175(4).

[38] Crinnion, W.J. (2011) Sauna as a valuable clinical tool for cardiovascular, autoimmune, toxicant-induced and other chronic health problems, Alternative Medicine Review, $16(3)$

[39] Tei, C., Horikiri, Y., Park, J-C., Jeong, J-W., Chang, K-S., Toyama, Y., and Tanaka, N. (1995) Acute Hemodynamic Improvement by Thermal Vasodilation in Congestive Heart Failure, Circulation, 91.

[40] Leppäluoto, J., Tuominen, M., Väänänen, A., Karpakka, J. and Vuori, J. (1986) Some cardiovascular and metabolic effects of repeated sauna bathing, Acta Physiologica Scandanavica, 128(1)

[41] Kukkonen-Harjula, K., Pekka Oja, P., Laustiola, K., Vuori, I., Jukka Jolkkonen, J., Simo Siitonen, S., and Vapaatalo, H. (1989) Haemodynamic and hormonal responses to heat exposure in a Finnish sauna bath, European Journal of Applied Physiology and Occupational Physiology, 58(5).

[42] Nguyen, Y., Naseer, N., and Frishman, W.H. (2004) Sauna as a Therapeutic Option for Cardiovascular Disease, Cardiology in Review, 12(6).

[43] Gayda, M., Paillard, F., Sosner, P., Juneau, M., Garzon, M., Gonzalez, M., Bélanger, M., and Nigam, A. (2012) Effects of Sauna Alone and Postexercise Sauna Baths on Blood Pressure and Hemodynamic Variables in Patients With Untreated Hypertension, The Journal of Clinical Hypertension, 14(8). 
[44] McCarty, M.F., Barroso-Aranda, J., Contreras, F. (2009) Regular thermal therapy may promote insulin sensitivity while boosting expression of endothelial nitric oxide synthase - Effects comparable to those of exercise training, Medical Hypotheses, 73(1).

[45] Lakka, T.A., Nyyssönen, K., and Salonen, J.T. (1994) Higher Levels of Conditioning Leisure Time Physical Activity are Associated with Reduced Levels of Stored iron in Finnish Men, American Journal of Epidemiology, 140(2).

[46] Ślężyński , T., Wołyńska, A., and Prystupa, J. (2009) The Effects of Finish Sauna on Hemodynamics of the Circulatory System in Men and Women, Journal of Human Kinetics, 22.

[47] Iiyama, J., Matsushita, K., Tanaka, N., and Kawahira, K. (2008) Effects of single low-temperature sauna bathing in patients with severe motor and intellectual disabilities, International Journal pf Biometeorology, 52(6).

[48] Stoops, J. L. (2004). A possible connection between thermal comfort and health. - Report Number: LBNL-55134.

[49] Kunutsor, S.K., Laukkanen, T., Laukkanen, J.A. (2017) Sauna bathing reduces the risk of respiratory diseases: a long-term prospective cohort study, European Journal of Epidemiology, 32(12).

[50] Redberg, R.F., (2015) Health Benefits of Sauna Bathing, JAMA Internal Medicine, 175(4).

[51] van der Wall, E.E. (2015) Sauna bathing: a warm heart proves beneficial, Netherlands Heart Journal, 23(5).

[52] Laukkanen, T., Kunutsor, S., Kauhanen, J., and Laukkanen, J.A. (2017) Sauna bathing is inversely associated with dementia and Alzheimer's disease in middle-aged Finnish men, Age and Ageing, 46(2).

[53] Kowatzki, D., Macholdt, C., Krull, K., Schmidt, D., Deufel, T., Elsner, P., and Fluhr, J.W. (2008) Effect of Regular Sauna on Epidermal Barrier Function and Stratum Corneum Water-Holding Capacity in vivo in Humans: A Controlled Study, Dermatology, 217(2).

[54] Sears, M.E., Kerr, K.J., and Bray, R.I. (2012) Arsenic, Cadmium, Lead, and Mercury in Sweat: A Systematic Review, Journal of Environmental and Public Health, 2012.

[55] Genuis, S.J., Birkholz, D., Rodushkin, I., Beesoon, S. (2011) Blood, Urine, and Sweat (BUS) Study: Monitoring and Elimination of Bioaccumulated Toxic Elements, Archives of Environmental Contamination and Toxicology, 61(2).

[56] Omokhodion, F.O., and Crockford, G. W. (1991) Lead in sweat and its relationship to salivary and urinary levels in normal healthy subjects, The Science of the Total Environment, 103(2-3).

[57] Kapka-Skrzypczak, L., Sawicki, K., Czajka, M., Turski, W.A., and Kruszewski M. (2015) Cholinesterase activity in blood and pesticide presence in sweat as biomarkers of children's environmental exposure to crop protection chemicals, Annals of Agricultural and Environmental Medicine, 22(3).

[58] Scoon, G.S., Hopkins, W.G., Mayhew, S., and Cotter, J.D. (2007) Effect of post-exercise sauna bathing on the endurance performance of competitive male runners, Journal of Science and Medicine in Sport, 10(4).
[59] Sunderman, F.W.Jr, Hohnadel, D.C., Evenson, M.A., Wannamaker, B.B., Dahl, D.S. (1974) Excretion of Copper in Sweat of Patients with Wilson's Disease During Sauna Bathing, Annals of Clinical and Laboratory Science, 4(5).

[60] Jezová, D., Kvetnanský, R., Vigas, M. (1994) Sex differences in endocrine response to hyperthermia in sauna, Acta Physiologica Scandanavica, 150(3).

[61] Leppäluoto, J., Huttunen, P., Hirvonen, J., Väänänen, A., Tuominen, M., and Vuori, J. (1986) Endocrine effects of repeated sauna bathing, Acta Physiologica Scandinavica, 128(3).

[62] Lammintausta, R., Syvälahti, E., and Pekkarinen A. (1976) Change in hormones reflecting sympathetic activity in the Finnish sauna, Annals of Clinical Research, 8(4).

[63] Kubota, K., Kurabayashi, H., Tamura, K., Kawada, E., Tamura, J., and Shirakura, T. (1992) A transient rise in plasma $\beta$-endorphin after a traditional $47^{\circ} \mathrm{C}$ hot-spring bath in Kusatsu-spa, Japan, Life Sciences, 51(24).

[64] Sutkowy, P., Woźniak, A., Boraczyński, T., Mila-Kierzenkowska, C., and Boraczyński, M. (2014) The effect of a single Finnish sauna bath after aerobic exercise on the oxidative status in healthy men, Scandinavian Journal of Clinical and Laboratory Investigation, 74(2).

[65] Toda, M., Morimoto, K., Nagasawa, S., and Kitamura, K. (2006) Change in salivary physiological stress markers by spa bathing, Biomedical Research, 27(1).

[66] Morgan, A.J., and Jorm, A.F. (2009) Self-help strategies that are helpful for sub-threshold depression: A Delphi consensus study, Journal of Affective Disorders, 115.

[67] Hayasaka, S., Nakamura, Y., Kajii, E., Ide, M., Shibata, Y., Noda, T., Murata, C., Nagata, K., Ojima, T. (2008) Effects of charcoal kiln saunas (Jjimjilbang) on psychological states, Complementary Therapies in Clinical Practice, 14(2).

[68] Colmant, S.A., Eason, E.A., Winterowd, C.L., Jacobs, S.C., \& Cashel, C. (2005) Investigating the Effects of Sweat Therapy on Group Dynamics and Affect, The Journal for Specialists in Group Work, 30(4).

[69] Penedo, F.J. \& Dahn, J.R. (2005) Exercise and well-being: a review of mental and physical health benefits associated with physical activity, Current Opinion in Psychiatry, 18(2):189-193.

[70] Wolf, E.M., Wrubel, J., Daubenmier, J.J., Price, C.J., Kerr, C.E., Silow, T., Gopisetty, V., \& Stewart, A.L. (2011) Body Awareness: a phenomenological inquiry into the common ground of mind-body therapies, Philosophy Ethics and Humanities in Medicine, 6(6).

[71] Astin, J.A. (2004) Mind-Body Therapies for the Management of Pain, The Clinical Journal of Pain, 20(1):27-32.

[72] Luskin, Frederic M; Newell, Kathryn A; Griffith, Michelle; Holmes, Margaret;Telles, S., DiNucci, E., Marvasti, F.F., Hill, M., Pelletier, K.R., \& Haskell, W.J. (2000) A review of $\mathrm{mind} /$ body therapies in the treatment of musculoskeletal disorders with implications for the elderly, Alternative Therapies in Health and Medicine, 6(2):46-56.

[73] Grossman, P., Niemann, L., Schmidt, S., \& Walach, H. 
(2004) Mindfulness-based stress reduction and health benefits, Journal of Psychosomatic Research, 57(1):35-43.

[74] Innes, K.E., Terry Kit Selfe, T.K., \& Ann Gill Taylor, A.G. (2008) Menopause, the metabolic syndrome, and mind-body therapies, HHS Public Access, 15(5):1005-1013.

[75] Coker, K.H. (1999) Meditation and prostate cancer: integrating a mind/body intervention with traditional therapies, Seminars in Urological Oncology, 17(2):111-118.

[76] Beddoe, A.E., \& Lee, K.A. (2008) Mind-Body Interventions During Pregnancy, Journal of Obstetric Gynecological \& Neonatal Nursing, 37(2):165-175.
[77] Morgan, N., Irwin, M.R., Chung, M., Wang, C. (2014) The Effects of Mind-Body Therapies on the Immune System: Meta-Analysis, PLOS ONE, 10.1371/journal.pone.0100903.

[78] Wolsko, P.M., Eisenberg, D.M., Davis, R.B. \& Phillips, R.S. (2004) MDUse of Mind-Body Medical Therapies, Journal of General Internal Medicine, 19(1):43-50.

[79] Helané Wahbeh, H., Siegward-M Elsas, S.M., \& Oken, B.S. (2008) Mind-body interventions: Applications in neurology, Neurology, 70(24).

[80] Jahnke, R., Larkey, L., Rogers, C., Etnier, J., Lin, F., (2010) Comprehensive Review of Health Benefits of Qigong and Tai Chi, American Journal of Health Promotion, 24(6). 